\title{
LISTS OF SPECIES
}

\section{Ants (Hymenoptera: Formicidae) and termites (Termitidae: Isoptera), Moron River basin, Carabobo, Venezuela: Preliminary data}

\author{
Miguel A. Riera-Valera, ${ }^{1 *}$ Antonio J. Pérez-Sánchez, ${ }^{2}$ and José Perozo ${ }^{3}$ \\ ${ }^{1}$ Universidad Central de Venezuela, Instituto de Zoología Agrícola. \\ Apartado 4579. Maracay 2101-A, Aragua, Venezuela. \\ ${ }^{2}$ Instituto Venezolano de Investigaciones Cientificas, Centro de Ecología, Laboratorio de Biología de Organismos. \\ Apartado 21827, Caracas 1020-A, Venezuela. \\ ${ }^{3}$ Instituto Nacional de Investigaciones Agrícolas, Centro Nacional de Investigaciones Agropecuarias. \\ Zona Universitaria, vía El Limón. Apartado 4653, Maracay, Aragua, Venezuela. \\ *Corresponding author. E-mail: rieramiguel@hotmail.com
}

\begin{abstract}
Nineteen ant species of six subfamilies (Dolichoderinae, Ecitoninae, Ectatomminae, Formicinae, Myrmicinae and Ponerinae) and two termite species (Termitidae) from Morón River basin (Carabobo, Venezuela) are listed here as part of a preliminary arthropod research. Despite of reporting a low number of taxa, this work constitutes the first record of ants from Morón, Carabobo state, Venezuela.
\end{abstract}

\section{Introduction}

Ants and termites are eusocial insects. There are 22 ants (Hymenoptera: Formicidae) subfamilies, and approximately 12,592 species described in almost all environments of the world (Agosti and Johnson 2005). For Venezuela some lists of ants have been published in the last two decades (e.g. Lattke 1985a; b; Jaffé et al. 1989). Unlike ants, termites (Isoptera) species belong to seven families (Mastotermitidae, Serritermitidae, Termopsidae, Hodotermitidae, Kalotermitidae, Rhinotermitidae and Termitidae) with 2,600 species described in the world (Gullan and Cranston 2005) and only three families are reported for the country (Kalotermitidae, Rhinotermitidae and Termitidae) with 58 species at the present time (Issa 2000).

Ants can nest in soil, trees, leaf litter or subsoil and may exhibit specialist or generalist diets (predators, leaf litter foragers, fungus growing ants) (Hölldobler and Wilson 1990; Kaspari 2003). However, termites nest in wood or ground and feed on wood and colony corpses (Pérez and Zavala 1995).

Moron River is the main source of water for Moron Petrochemical Complex and is next to human localities, harbor complex vegetation, and animal communities (Bisbal 1993; Díaz and Ortega 2006). In the last years, Morón River basin has been a target for some researches (e.g. Bisbal 1993; Díaz and Ortega 2006; Sevilla et al. 2009). However the information about insect composition (inventories) is still absent or restrict to sparse records of some groups (see. Issa 2000). Herein, as part of a preliminary arthropod study, this paper provides new records of ants and termites from Moron River basin in the Carabobo state, Venezuela.

\section{Material and Methods}

Morón River basin is located in the Morón valley at the north western of the state of Carabobo, county of Mora $\left(10^{\circ} 17^{\prime} \mathrm{N}-10^{\circ} 28^{\prime} \mathrm{N}, 68^{\circ} 10^{\prime} \mathrm{W}\right.$ $68^{\circ} 16^{\prime} \mathrm{W}$ ). This basin is compound of 12,000 ha of the Morón valley and contains two predominantly vegetation types: Tropical dry forest at $600-700 \mathrm{~m}$ of altitude and Wet premountain forest at 700-1,700 m (Ewel and Madriz 1976; Díaz and Ortega 2006). The annual mean precipitation is $1,178 \mathrm{~mm}$ and varies from 850 $\mathrm{mm}$ (low elevations) to $1,600 \mathrm{~m}$ (high elevations) (Bisbal 1993; Díaz and Ortega 2006; Sevilla et al. 2009). The temperature varies from $10-18{ }^{\circ} \mathrm{C}$ in high elevations to $33{ }^{\circ} \mathrm{C}$ in low elevation 
(Bisbal 1993; Díaz and Ortega 2006; Sevilla et al. 2009).

The collects were carried out by direct sampling (forceps) in four different points: i) near of the PEQUIVEN biological Station $\left(10^{\circ} 21^{\prime} 19^{\prime \prime} \mathrm{N}\right.$, $\left.68^{\circ} 13^{\prime} 18^{\prime \prime} \mathrm{W}\right)$; ii) $\left(10^{\circ} 21^{\prime} 46^{\prime \prime} \mathrm{N}, 68^{\circ} 13^{\prime} 26^{\prime \prime} \mathrm{W}\right)$; iii) $\left(10^{\circ} 19^{\prime} 56^{\prime \prime} \mathrm{N}, 68^{\circ} 13^{\prime} 51^{\prime \prime} \mathrm{W}\right)$; iv) $\left(10^{\circ} 19^{\prime} 23^{\prime \prime} \mathrm{N}\right.$, $68^{\circ} 13^{\prime} 55^{\prime \prime} \mathrm{W}$ ) (Figure 1). The method consisted in moving to different places collecting randomly in soil, litter, under stones and even in logs or trees (Romero and Jaffé 1989; Jaffé et al. 1989; Bestelmeyer et al. 2000; Sarmiento-M 2003) during 3 hours in each sample point, resulting in a collect effort of 12 hours/man. Termites species were identified by a specialist: Jorge Perozo, who is also one of the researchers. Part of the ants were indentified until genera and species level using the following keys: Lattke (1990), Palacio and Fernández (2003), and Arias-Penna (2007). The remaining ants were identified through comparison with material of the Museo del Instituto de Zoología Agricola (MIZA), Maracay, Venezuela (MIZA). All the ants were deposited in the MIZA collection.

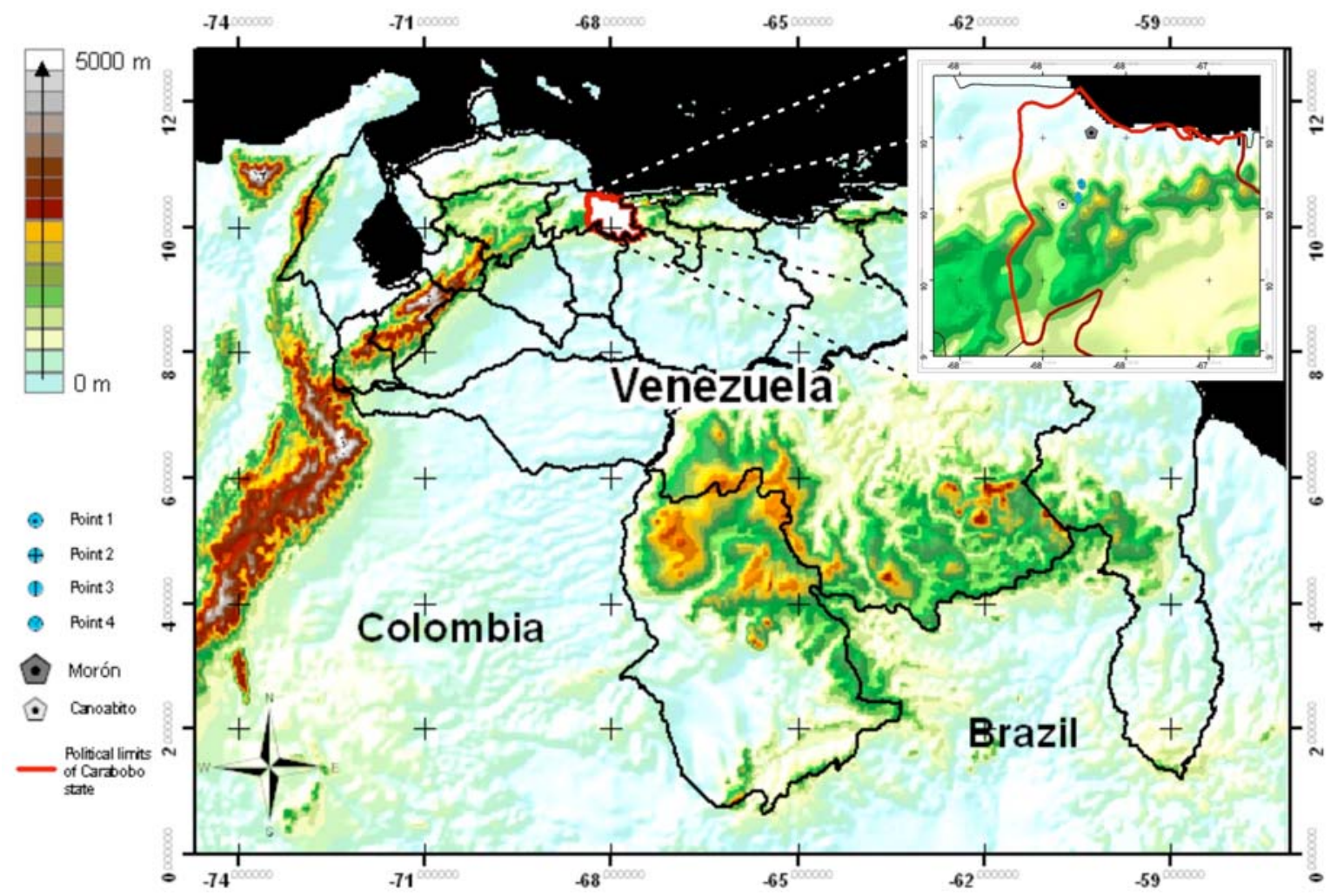

Figure 1. Sampling points at PEQUIVEN Biological Station in Morón River basin, state of Carabobo, Venezuela.

\section{Results and Discussion}

Nineteen species of ants and two species of termites were collected at the four sites. The ants listed here constitute the first record of the family Formicidae for Morón. However, Nasutitermes genus was already reported for the state of Carabobo (Issa 2000). The new records of ants and termites are listed below:

\section{FORMICIDAE}

Dolichoderinae

Dolichoderus sp. Carabobo, Cuenca de Morón, $10^{\circ} 21^{\prime} 19^{\prime \prime}$ N, 68 $18^{\circ} 18^{\prime \prime}$ W. 260 m. 9.IV.2008. F.
Nava, J. Valera, G. Peña, M. Riera. 167. Three workers.

Ecitoninae

Nomamyrmex sp. Carabobo, Cuenca de Morón, $10^{\circ} 21^{\prime} 46,1^{\prime \prime}$ N, 68 $133^{\prime} 26^{\prime \prime}$ W. 850 m. 9.IV.2008. F. Nava, J. Valera, G. Peña, M. Riera. 164. Collected from foraging column close to rotten log. Six workers.

Ectatomminae

Ectatomma tuberculatum (Olivier, 1972). Carabobo, Cuenca de Morón, 10²1'46" N, 
68¹3'26" W. 850 m. 9.IV.2008. F. Nava, J. Valera, G. Peña, M. Riera. 166. Foraging on leaf litter of Camp La Justa. Two workers.

Gnamptogenys annulata Mayr, 1887. Carabobo, Cuenca de Morón, 10²1'19" N, 68¹3'18" W. 260 m. 10.IV.2008. F. Nava, J. Valera, G. Peña, M. Riera. 173. Collected on sides of Quebrada la Justa. Two workers.

Formicinae

Camponotus sp. Carabobo, Cuenca de Morón, 10²1'19" N, 68¹3'18" W. 260 m. 9.IV.2008. F. Nava, J. Valera, G. Peña, M. Riera. 168. Four workers.

Brachymyrmex sp. Carabobo, Cuenca de Morón, 10²1'46" N, 68¹3'26" W. 850 m. 9.IV.2008. F. Nava, J. Valera, G. Peña, M. Riera. 164. Collected in tree. Three workers.

Myrmicinae

Atta sp. Carabobo, Cuenca de Morón, 10²1'19" N, 68¹3'18" W. 260 m. 9.IV.2008. F. Nava, J. Valera, G. Peña, M. Riera. 167. Four workers.

Cephalotes atratus (Linnaeus, 1758). Carabobo, Cuenca de Morón, 10²1'19" N, 6813'18" W. 260 m. 10.IV.2008. F. Nava, J. Valera, G. Peña, M. Riera. 173. Collected on sides of Quebrada la Justa. Two workers.

Crematogaster sp. Carabobo, Cuenca de Morón, $10^{\circ} 21^{\prime} 46^{\prime \prime}$ N, 68¹3'26" W. 850 m. 9.IV.2008. F. Nava, J. Valera, G. Peña, M. Riera. 164. Collected in tree. Five workers.

Megalomyrmex sp. Carabobo, Cuenca de Morón, 10¹9'56" N, 68¹3'51" W. 710 m. F. Nava, J. Valera, I. Pacheco, G. Peña, J. Jaspe, M. Riera. 171. Two workers.

Pheidole sp. 1 Carabobo, Cuenca de Morón, 10²1'19" N, 6813'18" W. 260 m. 10.IV.2008. F. Nava, J. Valera, G. Peña, M. Riera. 173. Three workers.

Pheidole sp. 2 Carabobo, Cuenca de Morón, 10²1'19" N, 6813'18" W. 260 m. 10.IV.2008. F. Nava, J. Valera, G. Peña, M. Riera. 173. Two workers.

Pheidole sp. 3 Carabobo, Cuenca de Morón, 10¹9'56" N, 68¹3'51" W. 710 m. F. Nava, J.
Valera, I. Pacheco, G. Peña, J. Jaspe, M. Riera. 170. Two workers.

Solenopsis sp. Carabobo, Cuenca de Morón, 10²1'19" N, 68³'18,1" W. 260 m. 10.IV.2008. F. Nava, J. Valera, G. Peña, M. Riera. 173. Three workers.

Trachymyrmex sp. Carabobo, Cuenca de Morón, 10²1'19" N, 6813'18" W. 260 m. 9.IV.2008. F. Nava, J. Valera, G. Peña, M. Riera. 168. In sides of Quebrada la Justa. Three workers.

Ponerinae

Odontomachus bauri (Emery, 1892). Carabobo, Cuenca de Morón, 10¹9'23" N, 68'13'55" W. 870 m. 9.IV.2008. F. Nava, J. Valera, I. Pacheco, G. Peña, J. Jaspe, M. Riera. 172. Foraging on soil. Four workers.

Pachycondyla apicalis (Latreille, 1802). Carabobo, Cuenca de Morón, 10²1'19" N, 68¹3'18" W. 260 m. 10.IV.2008. F. Nava, J. Valera, G. Peña, M. Riera. Foraging on log placed on sides of Quebrada La Justa. One woker.

P. harpax (Fabricius, 1804). Carabobo, Cuenca de Morón, 10¹9'56" N, 68¹3'51" W. 710 m. F. Nava, J. Valera, I. Pacheco, G. Peña, J. Jaspe, M. Riera. 171. Two workers.

P. stigma (Fabricius, 1804). Carabobo, Cuenca de Morón, 10²1'19" N, 68¹3'18" W. $260 \mathrm{~m}$. 10.IV.2008. F. Nava, J. Valera, G. Peña, M. Riera. 173. Collected on sides of Quebrada la Justa. One worker.

\section{TERMITIDAE}

Nasutitermes corniger (Motschulsky, 1855). Carabobo, Cuenca de Morón, 10²1'46" N, 68 13'26" W. 850 m. 9.IV.2008. F. Nava, J. Valera, G. Peña, M. Riera. 177. Collected in log of Campamento la Justa. Ten workers.

Nasutitermes macrocephalus (Silvestri, 1903). Carabobo, Cuenca de Morón, 10²1'46" N, 68¹3'26" W. 850 m. 9.IV.2008. F. Nava, J. Valera, G. Peña, M. Riera. Eight workers.

Despite of being a Neotropical habitat, the number of ant species recorded was considerably low. However, a solid effort was carried out (12 hour/man). This low richness may be consequence of the sampling method. In Tropical Savannas, 
this collect technique is the second most important method in ant surveys (Romero and Jaffe 1989); while in environments with high vertical stratification of vegetation (tropical forest) such sampling method is not recommended (Bestelmeyer et al. 2000). These results might be compared to Jaffé et al. (1989) who reported low species richness, using direct sampling by forceps, in Venezuelan tepuyes, and also Romero and Jaffé (1989) who reported low species richness with the same method in Venezuelan Llanos but compared to pitfall traps.

Our results showed a better representation of epigeaics ants than arboreals (Dolichoderus, Crematogaster) and hypogeaics (Brachymyrmex) ants, which mean that the sampling effort was more sensitive to ground-dwelling ants. The application of most systematic sampling methods, such as ALL (Ants of Leaf Litters) protocol, pitfall traps and canopy might increase the sampling effectiveness and the results in ant richness (Agosti and Alonso 2000, Bestelmeyer et al. 2000). In relation to termites, the used of baits should improve our results (Yeoh and Chow-Yan, 2007).

It is necessary to carry out a best inventory of Moron River basin, including the study of other groups of arthropods with appropriate sampling methods in order to have a comprehensive data base of them.

Acknowledgments: We would like to thank to Javier Valera (Museo del Instituto de Zoología Agrícola, MIZA), Francisco Nava and Aldemar Acevedo (Instituto Venezolano de Investigaciones Cientificas, IVIC) John T Longino (Evergreen College, USA) for his comments and Jesus "Chuo" Manzanilla from MIZA for organizing the field trip. Also to all the friends who work on PEQUIVEN Biological Station.

\section{Literature Cited}

Agosti D. and L.E. Alonso. 2000. The ALL Protocol: A Standard Protocol for the Collection of GroundDwelling Ants; p. 204-206 In D. Agosti, J. Majer, J. Alonso and T. Schultz, (ed.). Ants: Standard Methods for Measuring and Monitoring Biodiversity. Biological Diversity Handbook Series. Washington: Smithsonian Institution Press.

Agosti, D. and N.F. Johnson. 2005. Antbase. Electronic database accesible at http://osuc.biosci.ohiostate.edu/hymenoptera/tsa.sppcount?the taxon=For micidae. USA. Captured on 01 November 2009.

Arias-Penna T.M. 2007. Subfamilia Ectatomminae; p. 53-107. In E. Jimenez, F. Fernández, T.M. Arias and F. Lozano-Zambrano (ed.). Sistemática, biogeografía y conservación de las hormigas cazadoras de Colombia. Santa Fé de Bogota: Instituto de Investigaciones de Recursos Biológicos Alexander von Humboldt.

Bestelmeyer, B.T., L.E. Agosti, C.R. Brandão, W.T. Brown, J.H.C. Delabie and R. Silvestre. 2000. Field techniques for the study of ground-dwelling ants: an overview, description, and evaluation; p. 122145. In D. Agosti, J. Majer, J. Alonso and T. Schultz (eds.). Ants: Standard Methods for Measuring and Monitoring Biodiversity. Biological Diversity Handbook Series. Washington: Smithsonian Institution Press.

Bisbal, F.J. 1993. Inventario preliminar de la fauna de la Cuenca de Rio Morón, Estado Carabobo, Venezuela. Acta Cientifica Venezolana 44: 365382 .

Díaz, W. and F. Ortega. 2006. Inventario de recursos botánicos útiles y potenciales de la cuenca del rio
Morón, estado Carabobo, Venezuela. Ernstia 16(1): 31-67

Ewel, M.J. and A. Madriz. 1976. Zonas de vida de Venezuela. Memoria explicativa del mapa ecológico. Caracas: Editorial Sucre. 270 p.

Gullan P.J and P.S. Cranston. 2005. The Insects: an outline of entomology. Edinburg: Blackwell publishing Ltd. 505 p.

Hölldobler, B. and E.O. Wilson. 1990. The Ants. Cambridge: Belknap Press. 732 p.

Issa, S. 2000. A checklist of the termites from Venezuela (Isoptera: Kalotermitidae, Rhinotermitidae, Termitidae). Florida Entomologist 83(3): 379-382.

Jaffé, K., H. Romero and J.E. Lattke. 1989. Biosfera del Marahuaca y zonas adyacentes (Territorio Federal Amazonas) Venezuela. Acta Terramaris 1: 33-37.

Kaspari, M. 2003. Introducción a la ecología de las hormigas; $p$ 97-112 In F. Fernández (ed.). Introducción a las Hormigas de la región Neotropical. Bogotá: Instituto de Investigación de Recursos Biológicos Alexander von Humboldt.

Lattke, J. 1985a. Hallazgos de hormigas nuevas para Venezuela (Hymenoptera: Formicidae). Boletín de Entomología de Venezuela 4(10): 82-84.

Lattke, J. 1985b. Hormigas nuevas para Venezuela II (Hymenoptera: Formicidae). Boletín de Entomología de Venezuela 4(6): 51.

Lattke, J. 1990. Revision del genero Gnamptogenys en Venezuela. Acta Terramaris. 2: 1-48

Palacio, E. E. and F. Fernández. 2003. Claves para las subfamilias y géneros; p 233- 260. In F. Fernández 
(ed.). Introducción a las Hormigas de la Región Neotropical. Bogotá: Instituto de Investigación de Recursos Biológicos Alexander von Humboldt.

Pérez R. and Y. Zavala. 1995. Principios de entomología agrícola. Coro: Universidad Nacional Experimental Francisco de Miranda (UNEFM). 398 p.

Romero, H. and K. Jaffé. 1989. A comparision of methods for sampling ants (Hymenoptera: Fomicidae) in Savannas. Biotropica 21(4): 348-352.

Sarmiento-M, C.E. 2003. Metodologías de captura y estudio de las hormigas; p. 201-210 In F. Fernández (ed.). Introducción a las Hormigas de la Región Neotropical. Bogotá: Instituto de Investigaciones de Recursos Biológicos Alexander von Humboldt.
Sevilla, V.A., J.A. Comerma and O. Silva. 2009. Caracterización de la cuenca del río Canoabo en el Estado Carabobo, Venezuela. I. Análisis climático y de producción de agua. Agronomía Tropical 59(1): 33-44.

Yeoh, B.H. and C.-Y. Lee. 2007. Soil Arthropods Associated with Bait Stations. Sociobiology (49):187-196.

Received: March 2009

Revised: November 2009

Accepted: November 2009

Published online: December 2009

Editorial responsibility: Cristiano Lopes-Andrade 